\title{
A fala da periferia na obra Cidade de Deus
}

\author{
Marilene Rosa Miola ${ }^{1}$
}

\begin{abstract}
Resumo: O objetivo deste artigo é analisar o livro Cidade de Deus, de Paulo Lins (2002), e refletir sobre sua fala e fruição na literatura periférica. A narrativa tem como protagonista a própria favela e está dividida em três grandes capítulos, representados nas histórias de Inferninho, Pardalzinho e Zé Miúdo. Através desses personagens, o autor descreve minuciosamente o cotidiano da miséria, do crime e da disseminação da violência na mesma proporção do declínio da natureza. Apresenta, enfim, os bastidores de uma autorrepresentação literária.
\end{abstract}

Palavras-chave: Cidade de Deus; Violência; Linguagem periférica.

Resumen: El objetivo de este trabajo es analizar el libro Ciudad de Dios, de Paulo Lins (2002), y reflexionar sobre su discurso y el disfrute de la literatura periférica. La narración tiene la propia favela como protagonista y está dividida en tres capítulos principales representados en las historias de Inferninho, Pardalzinho y Zé Miudo. A través de estos personajes, el autor describe con detalle la vida cotidiana de la pobreza, la delincuencia y la propagación de la violencia, en proporción a la disminución de la naturaleza. De todos modos, el backstage de una obra literaria de auto-representación.

Palabras clave: Ciudad de Dios; Violencia; Habla periférica.

\section{Introdução}

O autor da obra Cidade de Deus, Paulo Lins, nasceu no Rio de Janeiro em 1958. Foi membro do grupo Cooperativa dos Poetas e publicou um livro de poesia intitulado Sobre o sol, em 1986. Ex-morador do Conjunto Habitacional Cidade de Deus, em Jacarepaguá, Zona Oeste do Rio de Janeiro, dedicou-se ao magistério, foi acadêmico do curso de Letras da Universidade Federal do Rio de Janeiro. Como bolsista da antropóloga Alba Zaluar, dedicou-se à pesquisa antropológica sobre a criminalidade e as classes populares, o que lhe possibilitou o ingresso na produção literária e também a escrita do livro que o

${ }^{1}$ Mestranda PPGL em Letras. Centro Universitário Ritter dos Reis/RS. A EAD como alternativa de formação de mediadores de leitura. marilene.miola@poa.ifrs.edu.br. 
tornaria mundialmente conhecido, traduzido em inúmeras línguas. Essa obra grandiosa foi proclamada por Hollanda:

pela primeira vez, e a partir da convivência estreita com as comunidades de periferia, incluindo-se bandidos e traficantes, temos uma detalhada anatomia do cotidiano da miséria e do crime no Brasil, agora com as cores da experiência vivida. Já não se trata mais da favela idealizada e separada do asfalto, mas da violência aberta e do inconformismo existentes nos novos conjuntos habitacionais, ou neofavelas, como as identifica o autor (HOLLANDA, 2010, p.1).

O livro Cidade de Deus permitiu que em 2002 os diretores Fernando Meirelles e Kátia Lund levassem sua história para as telas do cinema, numa grande produção, que a partir desse momento tematizou séries televisivas, outras produções cinematográficas e inúmeros documentários.

A narrativa do autor Paulo Lins tem como protagonista e objeto a favela Cidade de Deus, elemento de reflexo da sociedade. Inicia descrevendo as características físicas e particulares do empreendimento imobiliário que foi cedido para famílias de desabrigados das enchentes e sem teto que passavam necessidades no Rio de Janeiro. Nas primeiras páginas, o autor descreve minuciosamente a construção e o povoamento deste conjunto habitacional retratado no livro:

Por dia, durante uma semana, chegavam de trinta a cinquenta mudanças, do pessoal que trazia no rosto e nos móveis as marcas das enchentes. Estiveram alojados no estádio de futebol Mario Filho e vinham em caminhões estaduais. Em seguida, moradores de várias favelas e da Baixada Fluminense habitavam o novo bairro, formado por casinhas fileiradas brancas, rosa e azuis. Do outro lado do braço esquerdo do rio, construíram Os Apês. Todos com cinco andares. Os tons vermelhos do barro batido viam novos apês no corre-corre da vida, na disparada de um destino a ser cumprido (LINS, 2002, p. 17).

Intercalados à descrição do conjunto habitacional, seu espaço, o narrador aborda os casos que ocorrem com personagens conhecidos por Cabeleira, Marreco, Alicate, Salgueirinho, Pelé e Pará, personagens sem sobrenomes, mas 
com destacada atuação em atividades criminosas e violentas na disputa por melhores roubos e assaltos, sempre à espera "da boa" que, segundo eles, lhes possibilitaria mudar de vida. Apresenta também a distribuição geográfica da favela, descrita minuciosamente: "Cidade de Deus deu a sua voz para as assombrações dos casarões abandonados, escasseou a fauna e a flora, remapeou Portugal Pequeno e renomeou o charco: Lá em Cima, Lá na Frente, Lá Embaixo, Lá do Outro Lado do Rio e Os Apês" (LINS, p. 16). O povoamento da favela foi tanto que, a certa altura, o próprio bandido se pergunta: “- Quem era aquele pessoal? Será que viriam mais bichos-soltos? Lá nos Apês já tinha um monte de bandidos, do Outro Lado do Rio também, mas de uma coisa tinha certeza, ninguém seria mais respeitado do que ele" (Idem, p. 60), diz Inferninho (personagem da primeira parte da narrativa).

\section{Mosaico de personagens}

Cidade de Deus não é a história de uma só pessoa, é a história da favela em ação. Ação que não se resume somente à violência e ao tráfico de drogas (embalados por samba em todos seus momentos), mas sim, com vida própria, forma um impressionante mosaico com suas quebradas labirínticas e suas vielas. Numa linguagem que caracteriza essa favela e sua atmosfera, explorando os mais variados tipos e figuras, que se mostram apenas com apelidos e sem sobrenomes que, de uma ou de outra forma, se envolviam ou eram envolvidos na realidade vivenciada.

Experiência semelhante é relatada na obra Freakonomics, de autoria de Levitt e Dubner (2007, p. 89) que, traduzida para o Brasil em 2007, relata o interior de gangues americanas, em Chicago, onde traficantes se manifestam e ponderam que: “'Isto aqui é uma guerra, cara', [...] todo dia o pessoal se vira para sobreviver. A gente faz o que pode. Não temos alternativa, e se tiver que morrer, porra, é isso que os crioulos fazem para pôr comida em casa".

A riqueza de detalhes aparece na parte inicial do livro, na qual Lins se utiliza da história do líder do chamado Trio Ternura (formado pelos 
personagens Tutuca, Inferninho e Martelo), Inferninho, para narrar o princípio da violência no complexo residencial, já que o histórico familiar do personagem $^{2}$ denuncia seu avanço na profissão bandido. Nessa perspectiva, deixa claro que a violência - vista como um problema social, fruto da falta de oportunidade e educação - não é apenas assalto e tráfico de drogas, mas intolerância, rejeição, preconceito e discriminação. A violência destacada, com foco na favela, é constitutiva, estrutural e estruturante e, numa outra perspectiva da qual falaremos mais adiante, cultural. Na verdade, o que vemos é a representação do funcionamento interno de uma facção social, que é historicamente excluída e que parece pertencer a um mundo à parte. Tal violência bem como a disputa por venda de drogas, como forma de enriquecimento fácil e forma de levar a vida "na boa", é exemplificada no pensamento do personagem Sandro Cenoura sobre os trabalhadores assalariados que residem no conjunto habitacional, como ele mesmo fora um dia:

lembrou-se do tempo em que trabalhava de faxineiro na PUC, única vez a que se fantasiara de otário, pois sabia que não ficaria rico limpando as sujeiras que a brancalhada fazia, e só os otários trabalham com a certeza de que não vão desfrutar das coisas boas da vida. [...] maconha, cocaína, isso é que dava dinheiro (LINS, 2002, p. 358).

Aqui é possível fazer uma analogia com a obra dos renomados economistas Levitt e Dubner, na qual ponderam:

No passado, um negro semiqualificado em Chicago conseguia ganhar um salário decente trabalhando numa fábrica. Com essa opção escasseando, o tráfico passou a ser mais sedutor ainda. Que dificuldade havia nisso? O troço viciava tanto que até um idiota conseguia vendê-lo (crack) (LEVITT; DUBNER, 2007, p. 104).

2 "O pai, aquele merda, vivia embriagado, nas ladeiras do morro do São Carlos; a mãe era puta da zona, e o irmão, viado”. (LINS, 2002, p. 22) 
Em grande parte deste capítulo, a narrativa detalha o avanço da venda, distribuição e consumo, ainda controlado, de drogas ilícitas (maconha): "até aqui cocaína era rara" (LINS, 2002, p. 87); mas, na medida em que avançamos nas páginas, o crescente ingresso de drogas e armas é proporcional ao avassalador e chocante aumento da violência, marcado pelas palavras do narrador, que afirma: “A venda de cocaína nos Apês aumentava, era comum chegarem carros com gente de fora querendo comprar a droga. Os viciados continuavam a trazer eletrodomésticos, armas e joias para trocar por drogas" (LINS, p. 363).

Numa abordagem minuciosa, o autor retrata a sequência de crimes, que não se reduzem aos protagonistas da trama, mas a casos absurdos paralelos às tramas dos bandidos líderes de bocas-de-fumo. Tais ocorrências chocam e causam perplexidade no leitor, como no caso do marido traído que esquarteja vivo o filho que não era dele, entregando-o à sua mulher numa caixa de sapatos, ou do outro que cortou a cabeça do "Ricardão" e entregou-a para a mulher que o traiu, embalada numa sacola plástica:

Ajeitou o facão na mão direita, a marreta na esquerda, agachouse, esperou que ele passasse. Saiu nas pontas dos pés pelas costas e, com vários golpes, decepou-lhe a cabeça. Tirou um saco plástico de dentro do bolso da calça, colocou a cabeça ensanguentada com os olhos esbugalhados no saco, foi para casa e jogou-a no colo da adúltera (LINS, p. 70-71).

A violência se materializa no dia a dia e vai formando o tecido cultural das crianças de Cidade de Deus. Os meninos, na primeira parte, se ocupavam em ver heróis na televisão, brincar com pipas, tomar banhos de rio, ter aulas e a "iniciação" ao consumo de drogas, cotidiano que, gradativamente, vai se transformando em todos os sentidos. O mocinho da ficção das produções de faroeste hollywoodianas passa a "ziguezaguear" (LINS, p. 57) na forma material de mocinho-bandido, na realidade sem seu cavalo, mas armado para as emboscadas e matanças. As brincadeiras de pipas se alteram para representar/sinalizar a chegada das "cargas" de drogas. As crianças passam da 
pureza ao desvirtuamento, sendo reconhecidas e chamadas de "os caixasbaixas", pela tenra idade (em média sete anos) e por não terem dinheiro como bandidos de quadrilhas. Estes "anjos" da Cidade de Deus se sentiam humilhados, excluídos, oprimidos e acuados ao se submeterem a fazer pequenos favores aos bandidos (dominadores) em troca de restos de comida e "trouxinhas" de maconha; assim, ao crescerem, queriam ser "traficantes" para conquistar respeito, consideração, poder e muito dinheiro.

Ora, o grupo dos "caixas-baixas" via no bandido (opressor) a imagem de poder, força, liderança e comportamento agressivo, não como um herói, tampouco como líder de um negócio destrutivo, mas como referencial de respeitabilidade. O futuro dessas crianças era bastante incerto e instável, marcado pela pobreza, representada pela metáfora "armados de fome até os dentes" (LINS, 2002, p. 246). A falta de perspectiva dos menores, que deviam pequenos favores aos seus "protetores", deveria ser compensada com o ato de matar para se obter consideração e respeito dos demais. Já que o currículo de mortes era fundamental para a conquista de uma promoção no "plano de carreira $^{3 "}$ do crime e do tráfico de drogas, a competição pela liderança da bocade-fumo era disputada "tiro a tiro". Tornar-se traficante e 'fora da lei', para esse grupo, era a única forma de firmar uma identidade forjada e enganosa na condição que ocupavam de submissão e exclusão, dentro e fora da favela. Ainda tendo como referencial a obra de Levitt e Dubner,

Para a garotada criada num conjunto habitacional da zona pobre de Chicago, traficar crack é uma profissão glamourosa. Para muitos desses meninos, o emprego de chefe de quadrilha altamente visível e lucrativo - era de longe o melhor que achavam possível almejar (LEVITT; DUBNER, 2007, p. 96).

O caráter da transformação da favela ao longo dos 20 anos da narrativa marca a trajetória e a mudança de todos os personagens que compõem a trama. O conjunto habitacional se transforma em favela, as crianças se tornam

${ }^{3} \mathrm{Na}$ Cidade de Deus, o plano seguia determinada hierarquia: olheiro - vapor - soldado - gerente - bandido. 
bandidos, o estado se corrompe através de seus representantes - que teriam o dever de manter a ordem - e a natureza se torna ameaçada pelo sangue e pelo lixo: "O rio limpo; o goiabal, que, decepado, cedera lugar aos novos blocos de apartamentos; algumas praças, agora tomadas por casas; os pés de jamelão assassinados, assim como a figueira mal-assombrada e as mamoneiras - deram lugar às fábricas" (LINS, 2002, p. 11). Os valores sociais e humanos se transformam como um reflexo da modernidade.

O rio tem uma significação grande e poética no início do povoamento da favela-bairro, é descrito como exuberante em toda sua beleza, inocência e pureza:

Antigamente a vida era outra aqui neste lugar onde o rio, dando areia, cobra-d'água inocente, e indo ao mar, couro de pé roçando pele de flor, mangas engordando, bambuzais rebentando vento, uma lagoa, um lago, um laguinho, amendoeiras, pés de jamelão e o bosque de Eucaliptos. Na paz de quem não sabe da morte. E, como o bom braço ao rio volta, o rio, totalmente abraçado, ia ziguezagueando água, levando íris soltas em seu leito, deixando o coração bater em pedras. Ria o rio (LINS, 2002, p. 15).

Com o passar dos anos, com a progressão da narrativa, as repetições linguísticas e adjetivações assustadoras e horripilantes do rio (antes com suas águas limpas), agora poluído e desintegrado, assombram o leitor. Águas que não mais representam o sopro vital, mas sim o depósito de cadáveres.

Essa água, conforme exposto no Dicionário de Símbolos (CHEVALIER e GHEERBRANT, 1990, p. 16), é encarada em dois planos opostos: “a água é fonte de vida e fonte de morte, criadora e destruidora". Neste contexto, o símbolo da vida deixa de ter sentido ao não se reverter na purificação da alma, e sim, como portador de malefícios, na punição dos considerados pecadores na sociedade cruel da favela e na sociedade moderna, ao abandonar seus entes em diferentes e desconhecidos endereços. Segundo Benjamin (1985), é a representação do declínio da aura, ou seja, do esvaziamento de conteúdo não só da natureza, mas do próprio homem, conforme as linhas da narrativa nos relatam: 
notou que a água do rio encarnara. A vermelhidão precedera um corpo humano morto. Vermelhidão esparramando-se na correnteza, mais um cadáver. As nuvens apagaram as montanhas por completo. Vermelhidão, outro presunto brotou na curva do rio. Vermelhidão, novamente seguida de defunto. Sangue diluindo-se em água podre acompanhado de mais um corpo trajando calça jeans, tênis Adidas e sanguessugas sugando o líquido encarnado ainda quente. (LINS, 2002, p. 1314)

E o esplendor da beleza do rio e de sua natureza frutífera desaparece transforma-se em secura, aridez, e num rio manso... mas com vermelhidão.

Essa mescla de estilos de ações cada vez mais acirradas é que mantém uma constante tensão: quem será a próxima vítima? - seja da violência bélica (bala perdida), da violência sexual, ou do preconceito -, tudo é reflexo da violência interna (da favela) e externa (da sociedade). A realidade da obra é tão grotesca que se contrapõe à ficção; a natureza, à urbanização/modernização; o socialmente correto, à anarquia; costumes simples e pueris, à ambição do poder e violência; civilização, à barbárie; progresso, à decadência.

O que causa estranheza no leitor é o fato de o autor Paulo Lins durante toda a narrativa do livro descrever o mundo do crime e das quebradas, manifestado em pormenores e detalhes de forma chocante e assustadora, como forma de valorizar e chamar atenção para sua obra, numa conexão com a realidade cada vez mais presente no cotidiano das comunidades da periferia, realidade esta que respinga na sociedade como um todo - como no exemplo da seguinte passagem: "Renata de Jesus, minutos antes do tiroteio, olhava para todos que passavam, instalada em seu carrinho. Fazia beicinho, ria e chorava, ações comuns para quem tem sete meses de vida. [...] mas um tiro de escopeta estraçalhou sua cabeça" (LINS, 2002, p. 342).

A realidade se estabelece como um suspense em cada ação explícita dos personagens principais, donos de bocas-de-fumo, a cada desconfiança ou a cada atitude de passar alguém e, simultaneamente, a sua riqueza de detalhes demonstra o modo de vida no qual ele, autor, está inserido e comprometido ao fazer um relato de dentro para fora. Benjamin (1985) afirma que, através de 
transfigurações, o autor deve transformar sua obra em instrumento político, a miséria, em objeto de fruição, segundo os modismos mais aperfeiçoados, como sinônimo de luta e ocupação de espaço numa sociedade comprovadamente excludente.

A evolução da narrativa no livro, através da parte central e final, mostra que, de um lado, há o aumento da violência (por meio de armas e crimes bárbaros) e, de outro, a redução da idade daqueles que entram no mundo do crime, como na passagem abaixo:

- Aí, Baião, tu que nunca matou ninguém, vai lá e mata o cara! [...] Tu nunca matou ninguém, vai lá pra tu sentir como é que é morou? Marcelinho Baião segurou a pistola, suas mãos tremiam, o coração disparava. Tinha de seguir a ordem de Miúdo, pois era ele quem sempre lhe dava dinheiro para comprar um quilo disso ou daquilo, fora ele quem lhe dera força em seu primeiro assalto, sua vida melhorou depois que passou a andar com Miúdo. Engatilhou a pistola e saiu quebrando pelas pontas de cada prédio levando seu medo, seu nervosismo, a sagacidade dos seus dez anos de idade junto com a arma que mal lhe cabia nas mãos (LINS, 2002, p. 185).

O autor associa ao trocadilho de drogas pesadas e armas de grosso calibre - metralhadoras, granadas, pistolas, escopetas, dinamite, explosivos, artefatos blindados, detalhados em muitas das páginas do livro, como sinônimo de poder e força, favorável ao fortalecimento bélico - com a colaboração direta do poder público corrupto, através da polícia. O progresso armamentista favorece a aparição das facções criminosas do crime organizado, como Comando Vermelho e Falange Vermelha.

O destaque narrativo da primeira parte do livro é apresentado através do personagem Inferninho, citado anteriormente, bandido que inicia a formação das quadrilhas no conjunto habitacional Cidade de Deus. Uma vez que a ambição individual, as relações com as drogas e seu próprio consumo movem a criminalidade e movimentam a busca do dinheiro fácil, do poder e do bem viver, com vistas aos costumes burgueses. A ânsia de poder, alimentada pela 
ambição e pelo egoísmo individual, acaba culminando na morte de Inferninho no desfecho do primeiro capítulo:

Inferninho não esboçou reação. Uma tranquilidade sem sentido estabeleceu-se em sua consciência, um sorriso quase abstrato retratava a paz que nunca sentira, uma paz que sempre buscou naquilo que o dinheiro pode oferecer, pois, na verdade, não percebera as coisas mais normais da vida. Mas pode realmente haver paz plena para quem o viver fora sempre remexer-se no poço da miséria? Deitou-se bem devagar, tinha uma prolixa certeza de que não sentiria a dor das balas, aquela esperança de a morte ser realmente um descanso para quem se viu obrigado a fazer da paz das coisas um sistemático anúncio de guerra (LINS, 2002, p. 170-171).

\section{Roupagem expressiva e suas representações}

O livro Cidade de Deus reflete uma total liberdade de criação/recriação pelo emprego de uma linguagem diferente, através da palavra escrita e da fala de seus personagens, como sinônimo de poder social e recusa de sua alienação, surpreendendo pela visibilidade e notoriedade que assumiu após surgir nas telas do cinema; ou seja, no uso de uma nova roupagem linguística, específica e única da favela descrita, formatando uma renovação estrutural e nova visão de mundo, das relações sociais e sua representatividade. Segundo a estudiosa Covizzi, 
Constata-se a desintegração, seja na nova maneira de usar seu instrumento expressivo (língua, sons, cores), seja na nova maneira de encarar seu constante ponto de referência (a realidade). Não se trata mais de interpretação, exaltação, idealização, fidelidade, ou de puro jogo com relação à última, mas da desconfiança de um algo mais, de novas possibilidades formais; esgotados ou pouco expressivos os recursos linguísticos e temáticos tradicionais, apela-se para a adequação da nova realidade à expressão antiga ou para a criação de uma nova expressão. As manifestações literárias desse último tipo deixam um ressaibo de nova dimensão do mundo por uma constante facilmente determinável em comparação com a grande maioria da ficção precedente, de tendência inegavelmente realista, lógica ou racionalista. À expressão ficcional, que é representação da realidade subordinada ao conhecimento perceptual, opõe-se, no nosso século, uma expressão que, arbitrariamente, subverte aquele tipo de conhecimento (COVIZZI, 1978, p. 36).

O autor parece não demonstrar somente o desejo em narrar detalhes das quebradas da Cidade de Deus, mas o de representar, a partir desse espaço em que está inserido, as diferenças entre classes sociais nas relações sociais e de poder.

Na parte central do livro, a narrativa foca o personagem Pardalzinho. A protagonista da trama, a favela Cidade de Deus, está agora engajada no mundo do crime e do tráfico. Pardalzinho já é o melhor amigo e parceiro de boca-defumo de Inho, que passou a chamar-se Zé Miúdo. Nesta fase, o tráfico se encontra firmado através da delimitação de território pelas bases de vendas de drogas e do crime organizado, oportunidade em que o autor descreve também fatos, costumes e ocorrências no sistema prisional, assim como mecanismos de corrupção do sistema policial, no qual os brancos tinham salvo-conduto - "até mesmo na favela, os brancos tinham certa regalia se flagrados fumando maconha" (LINS, 2002, p. 255). Aqui, mais uma vez, fica clara a vontade de demonstrar formas de repressão como reafirmação do posto de opressor e oprimido, do incluído e do excluído.

A trama se amplia na magnitude da ambição do personagem Zé Miúdo que, desde pequeno (seis anos) mata a sangue frio. Sua lei é "passo todos os que possam me atrapalhar ou perturbar minha boca-de-fumo", assim, monta um 
sistema que atenda ao seu velho sonho e intenção de "ser o dono de tudo", de ser respeitado e reconhecido por toda a comunidade do conjunto habitacional. O personagem pode ser qualificado como ambicioso, prepotente, doentio, frio, sem escrúpulos, capaz de tudo para ser reconhecido sem "ser sugestionado", seja ao explorar crianças, matar sem ser punido, ou cometer qualquer tipo de atrocidade e ainda ser admirado: "temido por todos e querido pelas mulheres" (LINS, 2002, p. 51), ou seja, o mérito de ser respeitado implica no desrespeito a tudo e a todos, com as bênçãos de Ogum e Exu. Instala-se o caos, pelo medo, falta de esperança, falta de certeza; a dúvida e o duvidoso assombram a comunidade da Cidade de Deus.

Diante disso e buscando afirmação no poder através dos meios de comunicação, Zé Miúdo desejava ver a notícia estampada na mídia de que ele era um assassino em potencial - tornando-se assim temido até pelos demais criminosos - e ser o mais procurado pela polícia, porque, afinal, estar na mídia é ditar moda e fazer parte de um todo, ser reconhecido (mesmo com atributos negativos), é o não estar à margem, não estar alienado.

O cerne do livro tem como foco o personagem Pardalzinho que, apesar de bandido, fazia contraponto a Zé Miúdo. Ele representava o bom malando, o verdadeiro playboy da favela, ao tatuar no braço um enorme dragão e ser respeitado por seu carisma atentando pela política da boa vizinhança para com outros bandidos e, preferencialmente, com os cocotas do asfalto (moradores da Zona Sul, brancos e estudantes). Grupo a quem admirava e queria ser igual, isto é, imitá-los no visual (queimados do sol, cabelo crespo e parafinado, tatuagem no corpo), no vestir (roupas de grife) e até mesmo no namoro com as "branquelas" - "que pareciam felizes como os ricos" (LINS, 2002, p. 153).

Pardalzinho, ao afirmar "sou playboy", sucumbe à vida proporcionada pelo enriquecimento fácil através do tráfico, já que "sentia-se agora definitivamente rico, pois vestia-se como eles" (LINS, p. 238). O "eles", nesse caso, são os cocotas, que, como dito anteriormente, moram fora da Cidade de Deus. "Iria frequentar a praia do Pepino assim que aprendesse o palavreado deles. Na moral, na moral, na vida tudo é questão de linguagem" (LINS, p. 238). 
O personagem percebe que, para se integrar a esse grupo, não basta travestir-se em roupas de grife, é necessário que aprenda o palavreado deles, pois é a base para sua aproximação e aceitação. A identidade local dos cocotas está associada ao fazer linguístico, na forma de linguagem, palavreado.

A distância que separa Pardalzinho do grupo da cidade fica evidente na sua impossibilidade de deixar o atraso da favela e recuperar os avanços da modernidade e dos espaços ocupados pela sociedade do outro lado do muro (simbólico) que os separa. Ele deseja ser reconhecido e respeitado, mas reconhece que há uma diferença irremediável pela sua condição de excluído, negro, ex-presidiário e traficante. Apesar disso, Pardalzinho se destaca dos demais personagens, uma vez que sonhava e fazia planos futuros, um futuro que (para ele) parecia estar cada vez mais distante nesse universo sem muita perspectiva. O sonho de Pardalzinho era o de comprar um terreno onde houvesse água corrente, terra boa para o cultivo e pequenas casas de madeira para ele e os cocotas morarem. Era isso o que deveria fazer para viver entre pessoas de rostos límpidos por não conviverem cara a cara com a morte: “Nada daqueles crioulos com cara nervosa e sem dentes" (LINS, 2002, p. 271).

No dia em que estava mais feliz e próximo de realizar seu sonho, ou seja, ir-se da Cidade de Deus, Pardalzinho foi assassinado. A morte do bom malandro é chorada e cantada em letras de samba por namoradas, amigos, bandidos, na mesma linguagem que une, separa, corrompe, enfim, define suas vidas: matar ou morrer.

Na terceira e última parte da obra de Paulo Lins, além de já estar instalada a violência na favela Cidade de Deus, aumentam assustadoramente as guerras pelo domínio das bocas-de-fumo. Contando, ainda, com a colaboração da corrupta força policial (retratado na obra) ao facilitar o ingresso de armas pesadas, de grosso calibre - representando quem manda mais na imagem de sujeitos socialmente destrutivos. Nessa parte final, o diferencial é como um trabalhador assalariado, de boa índole, torna-se bandido, termo que, segundo algumas acepções do Dicionário Eletrônico Houaiss, significa: “indivíduo que 
pratica atividades criminosas; pessoa com sentimentos ruins; que faz sofrer, cruel, infeliz" (HOUAISS e VILLAR, 2009).

A violência associada ao boom da cocaína foi implacável na formação de quadrilhas e disputa por bocas-de-fumo. Além disso, os abusos sexuais contribuíram para a revolta e agregação de inimigos com sede de vingança, como é o caso da saga de do personagem Zé Bonito, que teve sua noiva violentada por Zé Miúdo. E é com o florescimento da brutalidade de ações do personagem Zé Miúdo que Paulo Lins fecha o terceiro capítulo de sua narrativa.

Os tiroteios e mortes, seja entre as quadrilhas (disputa de bocas-de-fumo) ou contra a força policial, eram acontecimentos diários e rotineiros. As vidas se entrecruzam na mesma proporção das mortes. Vida e morte são vias paralelas, marcadas, no livro, pela linguagem a cada eliminação, que é desprovida de qualquer sentimentalismo ou emoção, mas caracterizada pelo recurso da repetição expressiva como marca registrada das ações de crueldade praticadas pelo personagem Zé Miúdo - descrito como "miudinho, feio e baixinho" (LINS, 2002, p. 300) - que, ao rir estridente, fino e rápido (como registrado em diversas páginas da narrativa), definia sua ação de eliminação e prazer, a cada morte, com grandes comemorações com a "rapaziada do conceito" (LINS, p. 177), abrindo a boca-de-fumo para consumo liberado.

A representação da morte está bem marcada no final da segunda e da terceira parte, seja nas letras de sambas, numa linguagem fortemente expressiva, direta, ou por meio de aforismos, como "falha a fala, fala a bala" (LINS, p. 21); "quem cria cobra morre picado" (LINS, p. 290), povoada de gírias, palavrões, tecendo um novo universo na mudança semântica como revolução da forma, como mediação simbólica da selvageria dentro e fora da favela, num realismo social insuperável.

Assim, o autor de Cidade de Deus nos devolve aqui, sem piedade e sem subterfúgios, a empatia do falar da favela como grande conhecedor e engajado na luta de levar para fora, tornar visível na convocação para justiça social, pela reflexão e debate em direção aos direitos humanos e ao questionamento crítico 
na busca do espaço como "marcação local" (HOLLANDA, 2010), e do direito ao mercado literário, ao dar voz ao que, no princípio, era “o verbo" (LINS, 2002, p. 21), mas que se tornou texto, obra, materializou-se em palavras.

A representação da exclusão social e do preconceito está marcada pelo autor no próprio contexto da periferia, nas passagens narrativas como: “a única coisa ruim do Rio de Janeiro era a presença de crioulos por toda parte o loiro era filho de Deus, o branco Deus criou, o moreno era filho bastardo e o preto o Diabo cagou. Seres daquela raça de picolé de asfalto" (LINS, p. 53). Os personagens da burguesia tinham identidade, nomes e endereços, população que surge como referente legitimador para tudo o que lhes falta da hegemonia burguesa. Tal como o personagem Pardalzinho (que sucumbe aos prazeres e costumes da burguesia) que tem o preconceito e a discriminação social e racial como motivações claras para alegar que "tinha prazer em matar branco, porque o branco tinha roubado seus antepassados da África para trabalhar de graça, o branco criou a favela e botou o negro para habitá-la. Tudo, tudo que era bom, era dos brancos" (LINS, p. 176).

De acordo com Williams (1979), toda a representação de uma obra é mediada, é construída através de recursos de uma linguagem, de personagens, de cenas, de recursos técnicos e estéticos específicos, que servem à finalidade de elaboração de sentidos e de efeitos para os mesmos sentidos de quem a vê, o espectador. A obra de Lins está engajada numa versão de literatura da periferia, que se contrapõe ao que Vaz (2008, p. 235) chama de "arte enlatada produzida pelo mercado, só que na versão da periferia. Sem exotismos, mas carregada de engajamento".

Pode-se dizer que a obra carrega acento político e crítico, nela o escritor assume o papel de agente cultural ao mostrar o panorama social no qual se encontra inserido. Fala do Brasil, um Brasil de poesia, sangue e samba; ao mesmo tempo, é quase imperceptível a pessoa do autor, criador e narrador, ao revelar elementos cotidianos da periferia e as representações das relações humanas nas suas mais íntimas manifestações, as quais estabelecem as normas, os princípios e os valores sociais desta mesma periferia em que se encontra. Há 
um compromisso da parte do autor, que se preocupa em comandar a ação dessa mesma linguagem ao demarcá-la na brutalidade de alguns personagens e no uso da repetição como recurso expressivo, expondo uma expressão cultural dentro de uma nova roupagem da literatura marginal, periférica, na pósmodernidade.

Numa análise da contemporaneidade da obra de Paulo Lins, pode-se refletir com base nos estudos de Covizzi:

As elaborações contemporâneas não representam mais a realidade como tal, mas sim, são transfiguradas nas suas representações, de maneira a apreender a significação daquilo que querem através da ficção. $O$ seu caráter diferente vem exatamente da "lúcida consciência" que tem o autor, da necessidade de uma ação ordenadora sobre o caos (COVIZZI, 1978, p. 31).

A autora citada constata que a partir dos anos 60 ocorreu uma necessidade de elaboração de novos métodos críticos, levando as produções e representações literárias a movimentadas polêmicas, sendo este período chamado de "idade da crítica" (COVIZZI, p. 31). Sugere também que o novo autor já não goza da uma integridade física, psicológica e social, mas é marcado como um indivíduo da ambiguidade, podendo se constituir em vários: "o que importa constar é que ele não se considera mais o centro, o irradiador de tudo. Hoje não há mais centro. Pela impossibilidade de adotar atitudes rígidas, pela mudança acelerada que sofrem as coisas da noite para o dia" (COVIZZI, p. 32).

Essa concepção é enriquecida por Blumenthal (2011, p. 15) ao argumentar que "a criação artística caminha, de mãos dadas, com aquilo que acontece ao seu redor e acompanha as transições do mundo e da sociedade". Napoli (2011) complementa com a percepção de que a projeção do sujeito no mundo se transforma numa espécie de espelho através do qual contempla a si mesmo. Candido (1985, p. 19), em seu livro Literatura e sociedade, afirma que "a literatura é também um produto social, exprimindo condições de cada civilização em que ocorre", uma vez que a literatura tematiza as ações estruturantes de uma obra, funcionando como espelho da sociedade. 
Hutcheon (1991, p. 30), em sua Poética do Pós-Modernismo, define o caráter dinâmico e polêmico dessa estética revolucionária em que "o centro já não é totalmente válido. E, a partir da perspectiva descentralizada, o 'marginal' e o 'ex-cêntrico' assumem uma nova importância à luz do reconhecimento". A autora considera que:

O Pós-Modernismo é um processo cultural em andamento, em que se precisa de uma definição como estrutura aberta, em constante mutação, para que se possa organizar o conhecimento cultural e procedimentos críticos. [...] na arte pós-modernista ocorre uma eliminação de distância entre a de elite e a popular, a cultura de massa é que, indiscutivelmente, ampliou essa distância e, ao mesmo tempo, diversos autores reconhecem a simpatia do Pós-Modernismo pelas formas populares de arte (HUTCHEON, 1991, p. 40).

O autor Lins, ao transgredir os padrões do cânone, não nega suas convenções tradicionais, mas ruma para a quebra de paradigmas, inovando na forma de falar sobre cultura e produção literária. Uma vez que Hutcheon (1991, p. 30) defende que "a cultura com C (maiúsculo, e no singular) se transformou em culturas (com c minúsculo, e no plural) e isso parece estar ocorrendo pelo efeito do impulso homogeneizante da sociedade de consumo do capitalismo recente". A apresentação de uma qualidade diferente do que o leitor está acostumado em épocas anteriores exige do leitor mais que uma leitura, devido à quebra das convenções literárias, sua não-linearidade e a ruptura com o convencional, ideia fortalecida pela afirmação de Hollanda (2010, p. 4), que diz: "com o sucesso definitivo de Cidade de Deus, ficou claro que alguma coisa irreversível havia afetado a criação e o mercado literário. Talvez até um novo cânone (tradição) estivesse em processo de gestação". Numa mesma proporção, também a estranheza do leitor se verifica nas obras O Cortiço, de Aluísio de Azevedo, e Vidas Secas, de Graciliano Ramos, não pela versão mais brutal da vida, mas pela temática importante do pobre, do miserável.

Segundo Bauman (2001, p. 31), a sociedade da modernidade é "uma sociedade de 'indivíduos livres' - fez da crítica da realidade, da insatisfação com 'o que aí está' e da expressão dessa insatisfação uma parte inevitável e 
obrigatória dos afazeres da vida de cada um de seus membros". O autor argumenta que as mudanças que se operam sejam em profundidade e em espaços públicos, exibidas no modo como essa sociedade moderna opera e se perpetua pela sua variedade, ambiguidade e instabilidade. MV Bill, compositor e cantor de música rap, em parceria com Celso Athayde, deu notoriedade ao documentário Falcão, meninos do tráfico (2008), com a temática do morro, da miséria, da falta de perspectiva; argumentando que não sabe ao certo, mas que poderá ajudar a pensar e repensar as desigualdades sociais e os conceitos das relações humanitárias.

A literatura periférica (destacada na obra de Paulo Lins) é uma literatura que pede vez e voz, não somente no sentido de trazer à tona uma realidade de exclusão social recheada de violência e atentado contra a vida - numa linguagem que choca o leitor - as com algo mais, toca fundo ao abordar também a temática da corrupção do sistema público, para a falta de perspectiva do ser humano, pessoal e familiar na transgressão de regras e condutas.

Além de tudo isso, serve como um alerta para abreviação de expectativa de vida, já que a média de idade/vida gira em torno de 20 anos, para os bandidos. Tal ideia é reforçada pelo discurso de Benjamin (1985) como representação do declínio da aura, ou seja, o esvaziamento de conteúdo para quem já não pode realizar nenhuma experiência, devido às condições sociais de exclusão e perda de identidade, como seres humanos. Essa constatação fica clara uma vez que o nome dos personagens da favela Cidade de Deus são imitações do que representam e de como agem dentro da organização em que se inserem.

Não há como nos furtar de citar um dos mentores, representante maior e símbolo da literatura periférica, Ferréz (Reginaldo Ferreira da Silva), que luta para dar sentido e visibilidade "na passagem para um reconhecimento do valor das diferenças, e até das contradições" (HUTCHEON, 1991, p. 40) presentes nessa literatura, como um passo importante e experimental dos processos significativos em relação à arte e à cultura periférica. Ferréz associa-se a Lins ao demonstrar um grande comprometimento com o fator local por meio de suas 
falas. Tornando-se um representante refinado e não menos impactante da fala cotidiana de bairros pobres e violentos de São Paulo, e o faz principalmente pelo universo do hiphop, nas letras dos raps, apelando pela ação e luta pelo espaço territorial em prol da arte e da literatura da periferia.

Enfim, pode-se resumir a obra de Paulo Lins, Cidade de Deus, na letra da música Traficando informação ${ }^{4}$, do famoso rapper MV Bill (2011); como denúncia da discriminação e exclusão social e apelo para discussões e debate, fala escancarada do dia a dia da miséria e do crime, não só da favela, mas de uma violência aberta das comunidades da periferia, o que pode ser conferido já nas primeiras linhas: "Seja bem-vindo ao meu mundo sinistro, saiba como entrar; drogas, revólver, polícia, cachaça, saiba como evitar" e segue clamando por ações de justiça social, combate ao tráfico de drogas e corrupção do sistema de governo, mas especialmente um olhar para uma população que sofre e convive com perdas, medos e fracassos.

\section{REFERÊNCIAS BIBLIOGRÁFICAS:}

BAUMAN, Zygmunt. Modernidade líquida. Tradução: Plínio Dentzien. Rio de Janeiro: Zahar, 2001.

BENJAMIN, Walter. Obras escolhidas - Magia e técnica, arte e politica: ensaios sobre literatura e história da cultura. Tradução: Sergio Paulo Rouanet. São Paulo: Brasiliense, 1985.

BLUMENTHAL, Thiago. Grandes autores que sobreviveram ao Holocausto. In: Revista Conhecimento Prático Literatura, n. 34. São Paulo: Criativo Mercado Editorial, 2011. p. 15-19.

CANDIDO, Antonio. Literatura e sociedade. São Paulo: Nacional, 1985.

CHEVALIER, Jean; GHEERBRANT, Alain. Dicionário de símbolos. Mitos, sonhos, costumes, gestos, formas, figuras, cores, números. Rio de Janeiro: José Olympio, 1990.

4 Disponível no endereço eletrônico <http://letras.terra.com.br/mv-bill/80315/>. Acesso em: 12 jan. 2011. 
COVIZZI, Lenira Marques. Ensaios 49: o insólito em Guimarães Rosa e Borges. São Paulo: Ática, 1978.

HOLLANDA, Heloisa Buarque de. As fronteiras móveis da literatura. Última modificação em 18 ago. 2010. Disponível em: <http://www.heloisabuarquedehollanda.com.br/?p=67> Acesso em 31 jan. 2011.

HOUAISS, Antônio; VILLAR, Mauro de Salles. Dicionário eletrônico Houaiss de lingua portuguesa 3.0. Rio de Janeiro: Objetiva, 2009.

HUTCHEON, Linda. Poética do pós-modernismo: história, teoria, ficção. Rio de Janeiro: Imago, 1991.

LEVITT, Steven D.; DUBNER, Stephen J. Freakonomics: o lado oculto e inesperado de tudo que nos afeta. Tradução: Regina Lyra - PUC/RJ. Rio de Janeiro: Elsevier, 2007.

LINS, Paulo. Cidade de Deus. São Paulo: Companhia das Letras, 2002.

MV BILL. Traficando informações. Publicado na Web em 2011. Disponível em: <http://letras.terra.com.br/mv-bill/80315/> Acesso em 20 fev. 2011.

MV BILL; ATHAYDE, Celso (Produção e Direção). Falcão: meninos do tráfico. Documentário. Publicado na Web em 02 mar. 2008. Disponível em: <http://www.google.com.br/search?q=falc\%c3\%a3o:+meninos+ do+tr\%c3\%a1fico\&hl=pt-br \&client=firefox $\quad$-a\&hs=erf\&sa= g\&rls=org.mozilla:pt-br: official\&channel=s\&prmd=ivnsb\& source $=$ univ\&tbs $=$ vid: $1 \& \mathrm{tbo}=\mathrm{u} \& \mathrm{ei}=\mathrm{bi} 9 \mathrm{mtfhsh} 8-$ ztweir6nmaw\&ved=0ccqqqwq> Acesso em 31 jan. 2011.

NAPOLI, Tatiana. Cesário Verde, o poeta impressionista. In: Revista Conhecimento Prático Literatura. São Paulo: Criativo Mercado Editorial, n. 34, 2011, p. 51-55.

VAZ, Sérgio. Cooperifa: antropofagia periférica. Rio de Janeiro: Aeroplano, 2008.

WILLIAMS, Raymond. Marxismo e literatura. Rio de Janeiro: Zahar, 1979.

\section{REFERÊNCIAS COMPLEMENTARES}

AZEVEDO, Aluísio de. O Cortiço. Porto Alegre: L\&PM Editores, 1998.

FERRÉZ. Ninguém é inocente em São Paulo. Rio de Janeiro: Objetiva, 2006. 
FERRÉZ (Org.). Literatura marginal: talentos da escrita periférica. Rio de Janeiro: Agir, 2005.

RAMOS, Graciliano. Vidas Secas. Rio de Janeiro: Record, 2006. 